\author{
E.N. Orujlu
}

\title{
Phase equilibria in the $\mathrm{SnBi}_{2} \mathrm{Te}_{4}-\mathrm{MnBi}_{2} \mathrm{Te}_{4}$ system and characterization of the $\mathrm{Sn}_{1-\mathrm{x}} \mathrm{Mn}_{\mathrm{x}} \mathrm{Bi}_{2} \mathrm{Te}_{4}$ solid solutions
}

Acad. M. Nagiyev Institute of Catalysis and Inorganic Chemistry of Azerbaijan NAS, Baku, Azerbaijan, elnur.oruclu@yahoo.com

\begin{abstract}
The phase diagram of the $\mathrm{SnBi}_{2} \mathrm{Te}_{4}-\mathrm{MnBi}_{2} \mathrm{Te}_{4}$ system was established over the entire concentration range by means of differential thermal analysis and powder X-ray diffraction techniques. It was shown that the system is non-quasi-binary due to the incongruent melting character of $\mathrm{SnBi}_{2} \mathrm{Te}_{4}$ and $\mathrm{MnBi}_{2} \mathrm{Te}_{4}$ compounds, but it is stable below solidus. The formation of a continuous series of solid solutions with the tetradymite-like layered structure was observed. Due to ionic radius differences of $\mathrm{Mn}^{2+}$ and $\mathrm{Sn}^{2+}$, both unit cell parameters of solid solutions increase linearly with the increasing amount of $\mathrm{Sn}$. Phase equilibria above the solidus curve cannot be completed until the $\mathrm{SnTe}-\mathrm{MnTe}-\mathrm{Bi}_{2} \mathrm{Te}_{3}$ system fully studied.
\end{abstract}

Keywords: $\mathrm{SnBi}_{2} \mathrm{Te}_{4}-\mathrm{MnBi}_{2} \mathrm{Te}_{4}$ system, phase equilibria, solid solutions, tetradymite-like structure, topological insulator.

Received 17.02.2020; accepted 15.03.2020.

\section{Introduction}

Bismuth and antimony based layered chalcogenides are desirable novel materials for the future development of low-power electronic and spintronic devices as topological insulators since they are new states of quantum matter which both theoretically predicted and experimentally observed in some layered tetradymite type structured compounds, in particular $A^{\mathrm{IV}} B^{\mathrm{VI}}-A_{2}^{\mathrm{V}} B_{3}^{\mathrm{VI}}$ $\left(A^{I V}=\mathrm{Mn}, \mathrm{Ge}, \mathrm{Sn}, \mathrm{Pb} ; A^{V}=\mathrm{Sb}, \mathrm{Bi} ; B^{V I}=\mathrm{Se}, \mathrm{Te}\right)$ systems [1-6]. Doping van der Waals layered materials with magnetic impurities which could induce novel exotic phenomena have been a subject of intensive studies lately [7-14].

$\mathrm{MnBi}_{2} \mathrm{Te}_{4}$ is one of the three most well-known and studied intermediate phase in the $\mathrm{MnTe}-\mathrm{Bi}_{2} \mathrm{Te}_{3}$ pseudobinary system. It is the simplest of the $(\mathrm{MnTe}) \cdot\left(\mathrm{Bi}_{2} \mathrm{Te}_{3}\right)_{\mathrm{m}}$ family, being made up of seven-member blocks (Te-Bi-Te-Mn-Te-Bi-Te) along the $c$ axis and crystallize in the hexagonal $(R-3 m)$-type structure. And recently it was named as a first antiferromagnetic topological insulator [15]. However, while investigating $\mathrm{X}$-ray diffraction (XRD) patterns from cleaved surfaces of $\mathrm{Bi}_{2} \mathrm{Te}_{3}$ rich single crystals, the existence of other homologous members was suggested by the Refs [16,17], $(\mathrm{MnTe}) \cdot\left(\mathrm{Bi}_{2} \mathrm{Te}_{3}\right)_{\mathrm{m}}, \mathrm{m}=1 \ldots 4,5,6$. Due to these multilayer compounds form peritectic cascades in a very tiny temperature interval, it is extremely hard to grow their individual single crystals.

Despite long years carrying out research [18-20], the phase diagram of the $\mathrm{SnTe}_{\mathrm{T}}-\mathrm{Bi}_{2} \mathrm{Te}_{3}$ system is still uncertain. In early studies, three ternary compounds, namely $\mathrm{SnBi}_{2} \mathrm{Te}_{4}, \quad \mathrm{SnBi}_{4} \mathrm{Te}_{7}$, and $\mathrm{SnBi}_{6} \mathrm{Te}_{10}$ were reported, while two additional members, $\mathrm{Sn}_{2} \mathrm{Bi}_{2} \mathrm{Te}_{5}$ and $\mathrm{SnBi}_{8} \mathrm{Te}_{13}$ were mentioned in further investigations $[19,20]$. The $\mathrm{SnBi}_{2} \mathrm{Te}_{4}(R-3 m)$ is comprised of septuplelayer blocks stacked along the $c$ axis and crystallize into hexagonal unit cell just like $\mathrm{MnBi}_{2} \mathrm{Te}_{4}$ having the lattice constants $a=40.4035(4), \quad c=41.623(5) \quad$ [22], and $a=4.386, c=41.511$ [24].

In this paper, we investigate phase equilibria in the $\mathrm{SnBi}_{2} \mathrm{Te}_{4}-\mathrm{MnBi}_{2} \mathrm{Te}_{4}$ system since due to closeness of tin and manganese ionic radius there expected to have complete solid solubility between these two isostructural compounds. By tunning or modification, materials not only gain performance enhancement but also creates a chance to control desirable properties by adjusting the amount of substitutional atoms. The effect of various substitutional alloying elements in the similar systems 
were already investigated in [21-24]; however, $\mathrm{Sn}_{1-\mathrm{x}} \mathrm{Mn}_{\mathrm{x}} \mathrm{Bi}_{2} \mathrm{Te}_{4}$ system has not been studied before.

\section{Experimental part}

\subsection{Materials preparation and synthesis.}

The $\mathrm{Sn}_{1-\mathrm{x}} \mathrm{Mn}_{\mathrm{x}} \mathrm{Bi}_{2} \mathrm{Te}_{4}$ compounds were synthesized by using high purity elements $(99,999 \%$ purity from Alfa Aeser) in glassy carbon crucibles (avoid manganese side reactions) inside the quartz ampoules. Evacuated sealed ampoules $\left(10^{-3} \mathrm{~Pa}\right.$ residual pressure $)$ heated up to $700{ }^{\circ} \mathrm{C}$ for 3 hours and then air-quenched. However, DTA results (Fig. 1) of some newly synthesized samples showed the fraction of other phases were also presented. In order to achieve complete homogenization, all polycrystalline ingots were re-melted and quenched in ice water followed by annealing at $450{ }^{\circ} \mathrm{C}$ for $\sim 500 \mathrm{~h}$.

\subsection{Methods}

The resulting ingots analyzed by differential thermal analysis (DTA) and X-ray diffraction (XRD) methods. LINSEIS HDSC PT1600 system was used for DTA studies $\left(10 \mathrm{~K} \cdot \mathrm{min}^{-1}\right)$, while powder XRD patterns were taken on a Bruker D2 PHASER with $\mathrm{CuK}_{\alpha}$ radiation. The refinement of the structure and determination of the lattice parameters were carried out using the TOPAS 4.2 and EVA softwares.

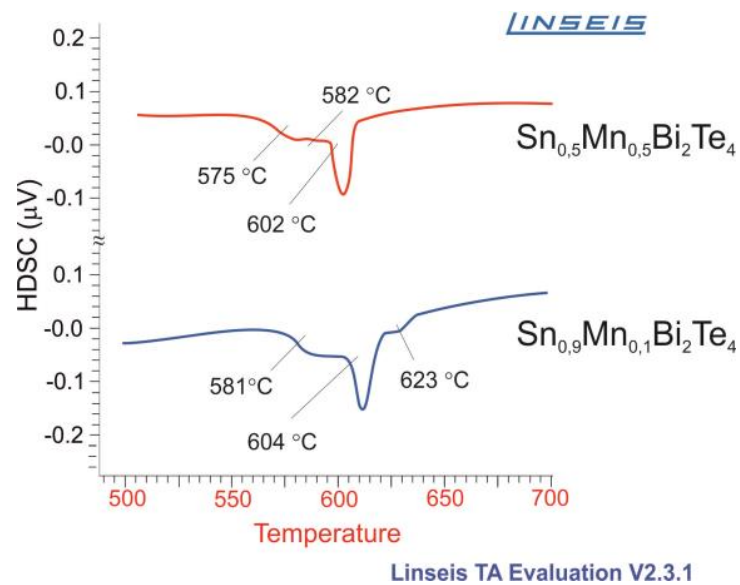

\section{Results and discussion}

Fig. 2a presents the PXRD patterns of some annealed $\mathrm{Sn}_{1-\mathrm{x}} \mathrm{Mn}_{\mathrm{x}} \mathrm{Bi}_{2} \mathrm{Te}_{4}$ alloys. It is clearly seen that each intermediate alloy has similar reflection lines with initial $\mathrm{SnBi}_{2} \mathrm{Te}_{4}$ and $\mathrm{MnBi}_{2} \mathrm{Te}_{4}$ compounds belong to tetradymite-type hexagonal structure with space group $R-3 m$. Further, increasing $x$ results of a slight shift of peaks to high angles arising from ionic radius differences which is characteristical for substitutional solid solutions.

Concentration dependence of lattice parameters of the $\mathrm{Sn}_{1-\mathrm{x}} \mathrm{Mn}_{\mathrm{x}} \mathrm{Bi}_{2} \mathrm{Te}_{4}$ solid solutions is shown in Fig. $2 \mathrm{~b}$. Our refinement results for initial $\mathrm{SnBi}_{2} \mathrm{Te}_{4}$ and $\mathrm{MnBi}_{2} \mathrm{Te}_{4}$ compounds good fit with literature data $[1,18,20]$. As expected, both lattice parameters increase linearly with increasing concentration of $\mathrm{Sn}$ content according to Vegard's law due to the larger radius of $\mathrm{Sn}^{2+}$ compared to $\mathrm{Mn}^{2+}$. Determined lattice parameters of some chosen compositions are listed in Table.

Based on the results of DTA analysis (Table 1) and PXRD examinations, the $\mathrm{T}-\mathrm{x}$ diagram of the $\mathrm{SnBi}_{2} \mathrm{Te}_{4}-\mathrm{MnBi}_{2} \mathrm{Te}_{4}$ system (Fig. 3) has been established. Heating termograms were used for the determination of decomposition temperatures, whereas liquidus points could not be evaluated thermal effects produced by heating and that's why liquidus was drawn

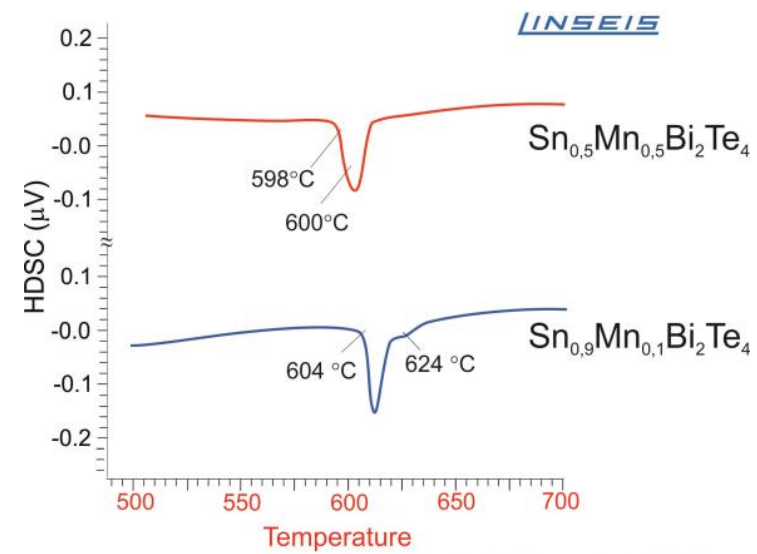

Linseis TA Evaluation V2.3.1

Fig. 1. DTA results of some alloys before and after annealing.

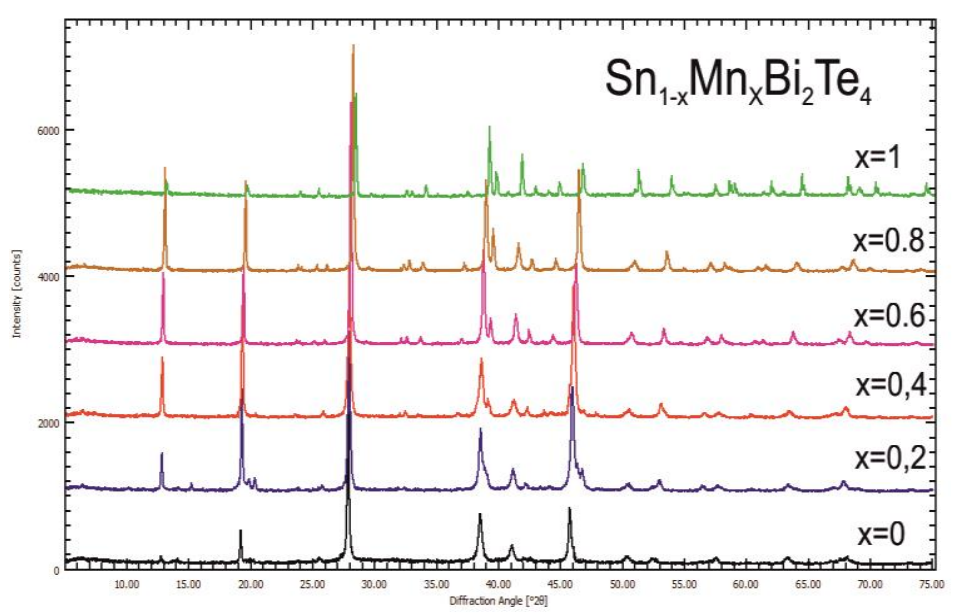

a)

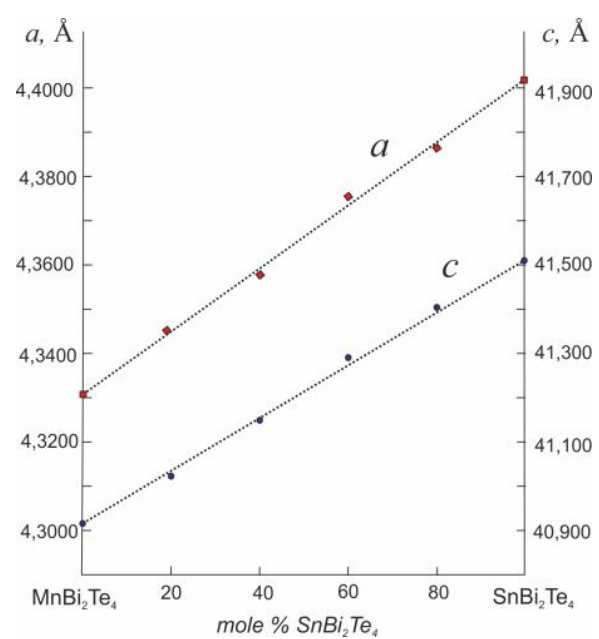

b)

Fig. 2. a) PXRD patterns and b) concentration dependence of lattice parameters of $\mathrm{Sn}_{1-\mathrm{x}} \mathrm{Mn}_{\mathrm{x}} \mathrm{Bi}_{2} \mathrm{Te}_{4}$ alloys. 
DTA measurements and determined unit cell parameters of $\mathrm{Sn}_{1-\mathrm{x}} \mathrm{Mn}_{\mathrm{x}} \mathrm{Bi}_{2} \mathrm{Te}_{4}$ alloys

\begin{tabular}{|c|c|c|c|}
\hline \multirow{2}{*}{$\begin{array}{c}\text { Alloy } \\
\text { mole }(\%)\end{array}$} & \multirow{2}{*}{ Thermal Effects $\left({ }^{\circ} \mathrm{C}\right)$} & $\boldsymbol{a}$ & Unit cell parameters $(\AA)$ \\
\cline { 3 - 4 } & & $4.4035(3)$ & $41.511(2)$ \\
\hline $\mathrm{SnBi}_{2} \mathrm{Te}_{4}$ & $606 ; 620$ & $4.3945(2)$ & $41.457(1)$ \\
\hline 90 & $604 ; 624$ & $4.3864(2)$ & $41.412(4)$ \\
\hline 80 & $602-604$ & $4.3769(4)$ & $41.295(5)$ \\
\hline 60 & $599-602$ & $4.3578(1)$ & $41.146(3)$ \\
\hline 40 & $596-598$ & $4.3455(4)$ & $41.021(2)$ \\
\hline 20 & $593-594$ & $4.3304(2)$ & $40.919(2)$ \\
\hline
\end{tabular}

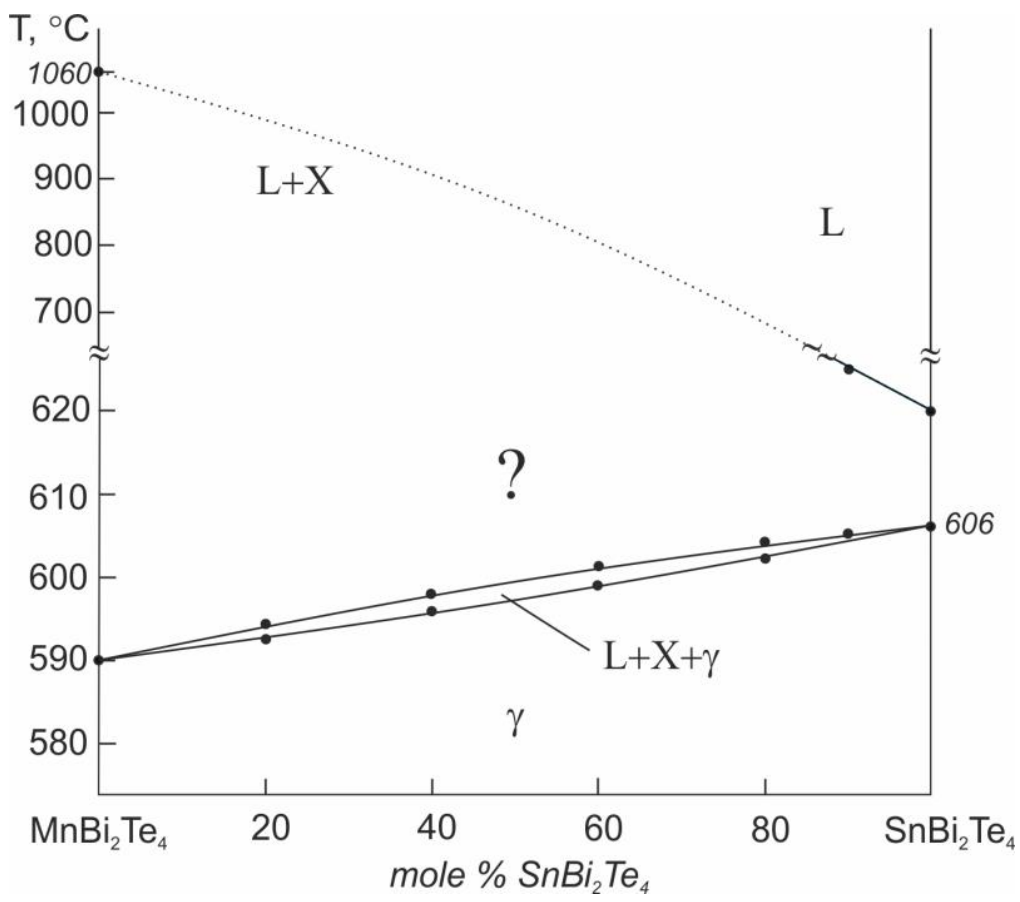

Fig. 3. T-x diagram of the $\mathrm{SnBi}_{2} \mathrm{Te}_{4}-\mathrm{MnBi}_{2} \mathrm{Te}_{4}$ system.

with a dotted line.

It is shown that below solidus the system is stable, and continuous solid solutions are formed in the whole composition range. Due to the incongruent melting character of $\mathrm{SnBi}_{2} \mathrm{Te}_{4}$ and $\mathrm{MnBi}_{2} \mathrm{Te}_{4}$ compounds, the system is not quasi-binary. As can be seen from the diagram, with an increasing amount of $\mathrm{Sn}$, the decomposition temperature increase gradually and the liquidus points fall.

Nevertheless, by using these results we cannot identify an alloy composition of the region between solidus and liquidus. Since the phase diagram of the $\mathrm{SnTe}-\mathrm{Bi}_{2} \mathrm{Te}_{3}$ and $\mathrm{MnTe}-\mathrm{Bi}_{2} \mathrm{Te}_{3}$ systems are quite complicated and have not been completed yet, it is not possible to define phase equilibria in the $\mathrm{SnBi}_{2} \mathrm{Te}_{4}-\mathrm{MnBi}_{2} \mathrm{Te}_{4}$ system at high temperatures. Initial compounds based phases may exist in this region; however interaction between $\mathrm{SnBi}_{2} \mathrm{Te}_{4}$ and $\mathrm{MnBi}_{2} \mathrm{Te}_{4}$ is rather complex and in order to complete the whole diagram, the ternary $\mathrm{SnTe}-\mathrm{MnTe}-\mathrm{Bi}_{2} \mathrm{Te}_{3}$ composition triangle must be studied fully.

\section{Conclusion}

In this paper, the phase relationship in the $\mathrm{SnBi}_{2} \mathrm{Te}_{4}-\mathrm{MnBi}_{2} \mathrm{Te}_{4}$ system was investigated over the entire concentration range and a phase diagram was constructed. The system is a non-quasi binary and forms continuous solid solutions with a tetradymite-like layered structure. The lattice parameters $a$ and $c$ increase in direct proportion to $x$ according to Vegard's law. The constructed phase diagram of the $\mathrm{Sn}_{1-\mathrm{x}} \mathrm{Mn}_{\mathrm{x}} \mathrm{Bi}_{2} \mathrm{Te}_{4}$ system is of great importance in terms of obtaining the magnetic topological insulator phases of given compositions.

Orujlu E.N. - Ph.D. student, Junior Researcher at the Department of Inorganic Functional Materials. 


\title{
E.N. Orujlu
}

[1] Z.S. Aliev, et al., J. Alloys Compd. 789, 443 (2019) (https://doi.org/10.1016/j.jallcom.2019.03.030).

[2] M.B. Babanly, et al., Russ. J. Inorg. 62(13), 1703 (2017) (https://doi.org/10.1134/S0036023617130034).

[3] S.V. Eremeev, et al., Phys. Rev. B, 91, 245 (2015) (https://doi.org/10.1103/PhysRevB.91.245145).

[4] K. Kuroda, et al., Phys. Rev. Lett. 108, 206803 (2012) (https://doi.org/10.1103/PhysRevLett.108.206803).

[5] M. Papagno, et al., ACS Nano 10 (3), 3518 (2016) (https://doi.org/10.1021/acsnano.5b07750).

[6] L.L. Wang, D.D. Johnson, Phys. Rev. B $\quad$ Condens. $\quad$ Matter. $83 \quad$ (24), 241309 (2011)(https://doi.org/10.1103/PhysRevB.83.241309).

[7] D. Niesner, et al., Phys. Rev. B 89, 081404 (2014) (https://doi.org/10.1103/PhysRevB.89.081404).

[8] Y. J. Chen, et al., Phys. Rev. X 9 (4), 041040 (2019) (https://doi.org/10.1103/PhysRevX.9.041040).

[9] C. Vidal Raphael et al., Phys. Rev. X 9(4), 041065 (2019) (https://doi.org/10.1103/PhysRevX.9.041065).

[10] J.-Q. Yan, et al., Phys. Rev. B100(10), 104409 (2019) (https://doi.org/10.1103/PhysRevB.100.104409).

[11] J. Teng et al., J. Semicond. 40 (8), 081507 (2019) (https://doi.org/10.1088/1674-4926/40/8/081507).

[12] J. Li, C. Wang, et al., Phys. Rev. B 100 (12), 121103 (2019) (https://doi.org/10.1103/PhysRevB.100.121103).

[13] A. Zeugner, et al., Chem. Mater. 31(8), 2795 (2019) (https://doi.org/10.1021/acs.chemmater.8b05017).

[14] J. Wu, et al., Sci. Adv. 5(11), eaax9989 (2019) (https://doi.org/10.1126/sciadv.aax9989).

[15] M.M. Otrokov, et al., Nature 576, 416 (2019) (https://doi.org/10.1038/s41586-019-1840-9).

[16] I.I. Klimovskikh, et al., arXiv preprint arXiv:1910.11653. (2019)

[17] Z.A. Jahangirli, et al., J. Vac. Sci. Technol. 37(6), 062910 (2019) (https://doi.org/10.1116/1.5122702).

[18] O.G. Karpinskii, et al., Inorg. Mater. 39(3), 240 (2003) (https://doi.org/10.1023/A:1022669323255).

[19] C. Chiu, et al., J. Electron. Mater. 41, 22 (2012) (https://doi.org/10.1007/s11664-011-1730-x).

[20] B.A. Kuropatwa, H.Z. Kleinke, Anorg. Allg. Chem. $638 \quad$ (15), 2640 (https://doi.org/10.1002/zaac.201200284).

[21] A.E. Seidzade, New Materials, Compounds and Applications 3(3), 193 (2019)

[22] A.E. Seidzade, M.B. Babanly, Azerbaijan Chemical Journal 4, 6 (https://doi.org/doi.org/10.32737/0005-2531-2019-4-6-10).

[23] Z.S. Aliev, Azerbaijan Chemical Journal 4, 54 (2019) (https://doi.org/doi.org/10.32737/0005-2531-2019-4-54$\underline{58}$.

[24] L. Pan, et al., Solid State Chem. 225, 168 (2015) (https://doi.org/10.1016/j.jssc.2014.12.016).

\section{Е.Н. Оруйлу}

\section{Фазова рівновага системи $\mathrm{SnBi}_{2} \mathrm{Te}_{4}-\mathrm{MnBi}_{2} \mathrm{Te}_{4}$ та характеристики твердого розчину $\mathrm{Sn}_{1-\mathrm{x}} \mathrm{Mn}_{\mathrm{x}} \mathrm{Bi}_{2} \mathrm{Te}_{4}$}

\author{
Інститут каталітичної та неорганічної хімії ім. акад. М. Нагієва НАН Азербайджану, Баку, Азербайджан
}

Встановлено фазові діаграми системи $\mathrm{SnBi}_{2} \mathrm{Te}_{4}-\mathrm{MnBi}_{2} \mathrm{Te}_{4}$ для всього діапазону концентрацій за допомогою диференціального термічного аналізу та методів порошкової рентгенівської дифракції. Показано, що система $\epsilon$ неквазібіонарною через нестандартне плавлення сполук $\mathrm{SnBi}_{2} \mathrm{Te}_{4}$ i $\mathrm{MnBi}_{2} \mathrm{Te}_{4}$, але є стабільною нижче солідуса. Спостерігалося утворення безперервного ряду твердих розчинів із шаруватою тетрадимітоподібною структурою. Через різниці в іонних радіусах $\mathrm{Mn}^{2+} \mathrm{i} \mathrm{Sn}^{2+}$ параметри обох елементарних комірок твердих розчинів лінійно збільшуються зі збільшенням кількості Sn. Фазова рівновага над кривою солідуса не може бути завершена до повного вивчення системи $\mathrm{SnTe}-\mathrm{MnTe}-\mathrm{Bi}_{2} \mathrm{Te}_{3}$.

Ключові слова: система $\mathrm{SnBi}_{2} \mathrm{Te}_{4}-\mathrm{MnBi}_{2} \mathrm{Te}_{4}$, фазова рівновага, тверді розчини, тетрадимітоподібна структура, топологічний ізолятор 